Kleczkowski, J. \& Kleczkowski, A. (1954). J. gen. Microbiol. 10, 285-293.

\title{
A Study of the Mechanism of Inhibition of Bacteriophage Multiplication by Chymotrypsin
}

\author{
BY J. KLECZKOWSKI AND A. KLECZKOWSKI \\ Rothamsted Experimental Station, Harpenden, Hertfordshire
}

SUMMARY: When $0.01 \%$ chymotrypsin is added to mixtures of rhizobium bacteriophage and bacteria in liquid cultures, the multiplication of phage is prevented and the phage gradually becomes inactive. The rate and extent to which phage and bacteria combine are unaffected by the chymotrypsin whose effect seems directed against an early stage in the interaction between the two. This stage persists, on average, for less than $1 \mathrm{~min}$. from the moment of combination. A phage particle combined with a bacterium becomes inactive and the bacterium is thus protected against lysis and remains able to multiply. Chymotrypsin does not interfere with combination between phage and bacteria killed by ultraviolet radiation; the combination leads to loss of phage activity irrespective of the presence of chymotrypsin. The multiplication of the phage is unaffected by previous incubation of either the phage or of the host bacteria separately with $0.01 \%$ chymotrypsin.

Chymotrypsin has no effect on phage-host interaction in an agar medium.

Ribonuclease, which apparently has no direct effect on a rhizobium bacteriophage, can nevertheless inhibit its multiplication in liquid bacterial cultures, probably by affecting host bacteria (Kleczkowski \& Kleczkowski, 1952). Chymotrypsin has now been found to be a much more efficient inhibitor of multiplication of the phage, although it does not affect directly either the phage or the bacteria in their abilities to interact with each other normally. The inhibitory effect of chymotrypsin, whose study is described in this paper, is directed against an early stage in the phage-host interaction.

\section{MATERIAL AND METHODS}

A phage which attacks a strain of clover nodule bacteria (Rhizobium trifolii, strain 317) was used. The media and the method of 'poured plates' for obtaining plaques were described previously (Kleczkowska, 1945 a).

Active phage was assayed by suitably diluting the fluids to be tested in $24 \mathrm{hr}$. liquid bacterial cultures; $1 \mathrm{ml}$. samples of this were mixed with $9 \mathrm{ml}$. of $0.7 \%$ agar medium, melted and cooled to $42^{\circ}$, and poured into a Petri dish of about $10 \mathrm{~cm}$. diameter. Plaques were counted after $48 \mathrm{hr}$. incubation at $\mathbf{2 5}^{\circ}$. When fluids contained bacteria and phage, these assays gave, of course, totals of 'active centres', i.e. of free phage and of infected bacteria.

Phage concentrations given below are mean numbers of plaques formed by $1 \mathrm{ml}$. samples of the diluted fluids, multiplied by the reciprocal of the dilutions.

Conclusions drawn from the results obtained in this work are unaffected by 'plating efficiency', i.e. by the magnitude of the ratio of estimated to actual phage concentrations, assuming this ratio to have been constant. It was probably near 1·0 (Kleczkowski \& Kleczkowski, 1951). 
Phage stock cultures were lysed liquid bacterial cultures passed through a Chamberland L3 filter. They usually contained about $10^{8}$ estimated phage particles/ml.

Liquid bacterial cultures were made by inoculating a loopful from an agar culture into $9 \mathrm{ml}$. of sterile liquid medium which was then incubated at $25^{\circ}$. After $24 \mathrm{hr}$. incubation the cultures contained c. $5 \times 10^{6}$ bacteria $/ \mathrm{ml}$. and after $48 \mathrm{hr}$. c. $10^{7} / \mathrm{ml}$.

Crystallized chymotrypsin was prepared from fresh beef pancreas as described by Northrop, Kunitz \& Herriot (1948). Chymotrypsinogen was recrystallized five times, then turned into chymotrypsin and recrystallized twice. Solutions of the crystals were dialysed for $48 \mathrm{hr}$. in cellophan sacks against frequently changed distilled water and then dried at $37^{\circ}$ in a flat dish placed in a desiccator. Weighed quantities of the dry material were dissolved in water immediately before use. In all experiments the $\mathrm{pH}$ of the various mixtures was between $\mathbf{7 \cdot 5}$ and $\mathbf{7 \cdot 7}$.

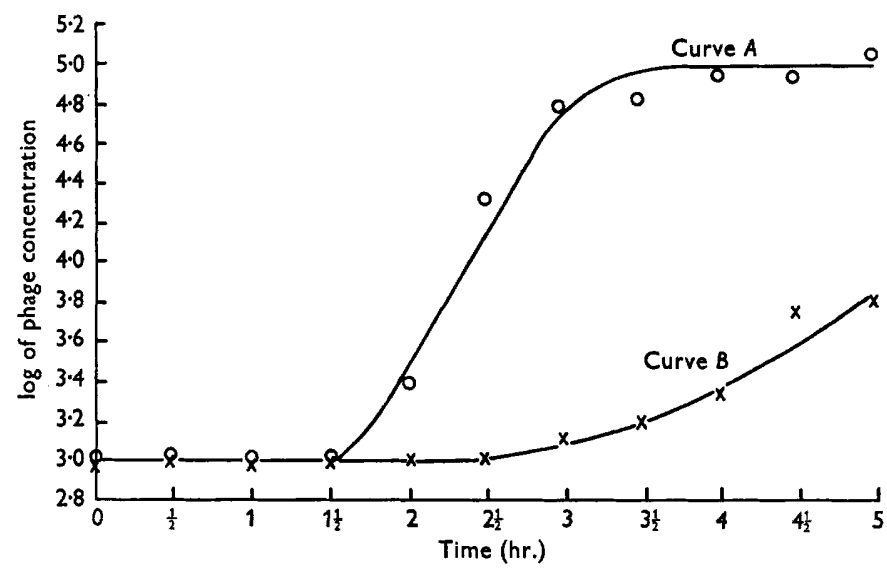

Fig. 1. The course of phage multiplication in liquid culture. Curve $\mathbf{A}$ : phage multiplication when there was no disturbance, i.e. when each sample for assay was taken from a different tube. Curve B: phage multiplication when a culture was disturbed by stirring during the taking of samples at $30 \mathrm{~min}$. intervals.

\section{RESULTS}

\section{Combination and multiplication of phage}

The designs of all main experiments in this work were based on three features of phage-host interaction which must be remembered in the interpretation of the results. First, the relatively slow rate of combination of the phage with the host bacteria (Table 4). Secondly, the 90 min. duration of the latent period (at $25^{\circ}$ ) followed by $90 \mathrm{~min}$. period of liberation of phage from infected cells, each cell producing on average about 100 phage particles (curve $A$, Fig. 1). Thirdly, the decrease in the rate of phage multiplication caused by frequent disturbances of cultures. The effect of these disturbances is seen from comparison of curves $\boldsymbol{A}$ and $\boldsymbol{B}$, Fig. 1. Curve $\boldsymbol{A}$ shows phage multiplication 
when there was no disturbance, when samples for each assay were taken from different tubes. Curve $B$ was obtained when all samples were taken from the same tube which was thus disturbed every $30 \mathrm{~min}$. Whether the stirring inseparable from taking representative samples affects combination between phage and bacteria, or disturbs development of phage within bacterial cells, is unknown, but, as Fig. 1 shows, the effect is considerable and must be allowed for in designing experiments.

\section{Effect of chymotrypsin (CTR)}

Table 1 shows that the presence of CTR in solidified agar medium did not prevent plaques forming or appreciably affect their number until the concentration of CTR in the fluid to be mixed with the agar medium and plated reached $0.1 \%$ (i.e. $0.01 \%$ in the agar medium), when the number was decreased by about $25 \%$. Thus, plaque counts can be used to assay concentration of active phage in the presence of CTR, provided the plated bacterial culture contains less than $0 \cdot 1 \% \mathrm{CTR}$ and that the plating is done immediately after dilution in the culture of the fluid to be tested. When the plated culture contains more than $0.001 \%$ C'TR, delay in plating allows a proportion of phage to combine with the bacteria and become inactivated, thus decreasing the number of plaques.

The inability of $0.01 \%$ CTR to prevent plaque formation (test no. 2, Table 1) contrasts sharply with its ability to stop phage multiplication in liquid bacterial cultures. Similarly, its ability to inactivate phage in liquid bacterial cultures (test no. 1, Table 2) contrasts with its inability to do so in the absence of bacteria (test no. 6, Table 2). It is not clear why CTR cannot act similarly in agar medium. Its adsorption by agar, its too slow diffusion through the agar, or the formation of a protective coating of agar on the bacterial surface are possible reasons.

Table 1. Plaque formation in the presence of chymotrypsin

\begin{tabular}{|c|c|c|c|c|c|c|c|}
\hline \multirow{3}{*}{$\begin{array}{c}\text { Test } \\
\text { no. }\end{array}$} & \multicolumn{6}{|c|}{ Composition of mixtures } & \multirow{3}{*}{$\begin{array}{l}\text { Nos. of } \\
\text { plaques on } \\
\text { four plates }\end{array}$} \\
\hline & \multirow{2}{*}{$\begin{array}{c}24 \mathrm{hr} . \\
\text { bacterial } \\
\text { culture (ml.) }\end{array}$} & \multicolumn{3}{|c|}{ Chymotrypsin (ml.) } & \multirow{2}{*}{$\begin{array}{c}\mathrm{H}_{2} \mathrm{O} \\
\text { (ml.) }\end{array}$} & \multirow{2}{*}{$\begin{array}{l}\text { Phage at a } \\
\text { dilution of } \\
\text { of } 10^{-5}(\mathrm{ml} .)\end{array}$} & \\
\hline & & $1.0 \%$ & $0.1 \%$ & $0.01 \%$ & & & \\
\hline 1 & 4 & 0.5 & - & - & 一 & 0.5 & 320 \\
\hline 2 & 4 & - & 0.5 & - & - & 0.5 & 415 \\
\hline 3 & 4 & - & - & 0.5 & - & 0.5 & 420 \\
\hline 4 & 4 & - & - & - & $0 \cdot 5$ & 0.5 & 440 \\
\hline
\end{tabular}

$9 \mathrm{ml}$. of $0.7 \%$ agar medium melted and cooled to $42^{\circ}$ was mixed with $1 \mathrm{ml}$. samples of the above mixture and poured into Petri dishes.

The rate of bacterial multiplication in liquid cultures was not affected by CTR at concentrations up to $0 \cdot 1 \%$. The only observed effects of CTR on bacteria were that in $0.1 \%$, but not in $0.01 \%$ CTR, the bacteria tended to form loose aggregates composed of a few cells, and that at both concentrations of CTR the motile cells that normally occur were not produced.

To see whether CTR alters bacteria and makes them unable to interact 
normally with the phage, $24 \mathrm{hr}$. bacterial cultures were incubated for a further $24 \mathrm{hr}$. with $0.01 \%$ CTR, the cells were then spun down, suspended in fresh medium and phage added to the suspension. Phage multiplied in the suspension at the same rate as did phage added to a comparable bacterial suspension which had not been exposed to CTR.

Table 2. Effect of chymotrypsin on phage multiplication in liquid cultures

Composition of mixtures

\begin{tabular}{|c|c|c|c|c|c|c|c|c|c|c|c|}
\hline \multirow[b]{2}{*}{$\begin{array}{c}\text { Test } \\
\text { no. }\end{array}$} & \multirow{2}{*}{$\begin{array}{c}24 \mathrm{hr} . \\
\text { bacterial } \\
\text { culture } \\
(\mathrm{ml} .)\end{array}$} & \multirow[b]{2}{*}{$\begin{array}{l}\text { Medium } \\
\quad(\mathrm{ml} .)\end{array}$} & \multicolumn{4}{|c|}{ Chymotrypsin (ml.) } & \multirow[b]{2}{*}{$\begin{array}{l}\mathrm{H}_{2} \mathrm{O} \\
\text { (ml.) }\end{array}$} & \multicolumn{4}{|c|}{ Concentration of active phage after } \\
\hline & & & $0 \cdot 1 \%$ & $0.04 \%$ & $0.01 \%$ & $0.0025 \%$ & & $0 \mathrm{hr}$. & $3 \mathrm{hr}$. & 24. hr. & $48 \mathrm{hr}$. \\
\hline $\mathbf{1}$ & 4 & - & 0.5 & - & - & - & - & 650 & 50 & 3 & 0 \\
\hline 2 & 4 & - & - & 0.5 & - & - & - & 670 & 250 & 6200 & $40 \times 10^{8}$ \\
\hline 3 & 4 & - & - & - & 0.5 & - & - & 660 & 6500 & $50 \times 10^{8}$ & - \\
\hline 4 & 4 & - & 一 & - & - & 0.5 & - & 700 & $8 \times 10^{4}$ & $45 \times 10^{8}$ & $35 \times 10^{8}$ \\
\hline 5 & 4 & - & - & - & - & - & $0.5)$ & & $8 \times 10^{4}$ & $45 \times 10^{8}$ & $35 \times 10^{8}$ \\
\hline 6 & - & 4 & 0.5 & - & - & - & $-\}$ & 700 & - & - & 690 \\
\hline 7 & - & 4 & - & - & - & - & 0.5 & & - & - & 680 \\
\hline
\end{tabular}

$0.5 \mathrm{ml}$. of phage diluted $10^{-5}$ was added to each mixture which was then incubated at $25^{\circ}$.

Table 3. Combination between phage and bacteria in the presence of chymotrypsin

Composition of mixtures

\begin{tabular}{|c|c|c|c|c|c|c|c|}
\hline $\begin{array}{l}\text { 24 hr. } \\
\text { bacterial } \\
\text { culture } \\
\text { (ml.) }\end{array}$ & $\begin{array}{r}\mathrm{H}_{2} \mathrm{O} \\
\text { (ml.) }\end{array}$ & $\begin{array}{l}0 \cdot 1 \% \\
\text { CTR } \\
\text { (ml.) }\end{array}$ & $\begin{array}{l}\text { Phage at } \\
10^{-4} \\
\text { (ml.) }\end{array}$ & $\begin{array}{l}\text { After } \frac{1}{2} \mathbf{h r} \text {. } \\
\text { incubation } \\
\text { at } 25^{\circ}\end{array}$ & & $\begin{array}{c}\text { Test } \\
\text { no. }\end{array}$ & $\begin{array}{c}\text { Mean } \\
\text { numbers } \\
\text { of plaques } \\
\text { per plate }\end{array}$ \\
\hline $3 \cdot 2$ & 0.4 & - & 0.4 & $\left\{\begin{array}{l}2 \mathrm{ml} . \text { not centrifuged } \\
2 \mathrm{ml} \text {. centrifuged }\end{array}\right.$ & $\left\{\begin{array}{l}\text { supernatant } \\
\text { sediment } \dagger\end{array}\right.$ & $\begin{array}{l}\mathbf{1} \\
\mathbf{2} \\
\mathbf{3}\end{array}$ & $\begin{array}{r}112 \\
42 \\
64\end{array}$ \\
\hline $3 \cdot 2$ & - & 0.4 & 0.4 & $\left\{\begin{array}{l}2 \mathrm{ml} . \text { not centrifuged } \\
2 \mathrm{ml} \text {. centrifuged } *\end{array}\right.$ & $\left\{\begin{array}{l}\text { supernatant } \\
\text { sediment } \dagger\end{array}\right.$ & $\begin{array}{l}4 \\
5 \\
6\end{array}$ & $\begin{array}{r}35 \\
40 \\
8\end{array}$ \\
\hline
\end{tabular}

As chymotrypsin does not seem to affect separately either phage or host bacteria in their abilities to interact with each other normally, it presumably affects directly the course of their interaction. The possibility that it interferes with combination between phage and bacteria was excluded as it did not alter the amounts of phage remaining in the supernatant fluids when phage + bacteria mixtures were centrifuged to remove the bacteria (compare tests nos. 2 and 5 , Table 3). Furthermore, the concentration of active phage in the CTR-containing mixtures remained unaffected by the removal of the bacteria (compare tests nos. 4 and 5, Table 3). The phage that had combined with 
bacteria had been rendered inactive by CTR. This effect of CTR could not be reversed by removing phage-infected bacteria from CTR-containing medium and placing them in fresh medium (compare tests nos. 3 and 6, Table 3). Most or all of the phage that was combined with bacteria in the presence of CTR remained inactive. The few plaques obtained in test no. 6 could have resulted from contamination of the bacterial sediment with uncombined phage or from activity of a small proportion of combined phage.

To see how long CTR takes to inactivate phage combined with bacteria, phage + bacteria mixtures, with and without CTR, were diluted at intervals to 1/100, which brought the concentration of CTR well below its limiting effective level and also decreased very considerably the rate of further combination between phage and bacteria (Table 4). Phage was assayed after $4 \mathrm{hr}$. incubation.

In test no. 9 the bacterial culture and phage had both been diluted 1/1000 before they were mixed (the mixture $\mathrm{C}$ ). The amount of phage formed at the end of $4 \mathrm{hr}$. incubation is assumed to be the amount that combined with bacteria, in time to multiply and be released by the end of the incubation, multiplied by 100 , plus the amount that did not combine. The phage increased $3 \cdot 1$ times, so that if $\rho$ is the proportion that combined, $100 \rho+(1-\rho)=3 \cdot 1$, therefore $\rho$ is about $\mathbf{0 . 0 2}$. It is assumed, therefore, that after the mixtures $\mathbf{A}$ and $B$ of Table 4 had been diluted $1 / 1000$, the proportion of phage, still remaining free, that combined with bacteria subsequently and multiplied was not greater than $\mathbf{0 \cdot 0 2}$. This is small in relation to proportions $(P)$ combined before the dilutions were made and is therefore neglected in computing these proportions for tests nos. 6-8, where there was no CTR.

The proportions of phage still active at the time of dilution, despite being combined in the presence of $0.01 \%$ CTR (i.e. before the mixture A was diluted), were computed by making two assumptions. First, that the proportion $(\boldsymbol{P})$ combined was unaffected by CTR. Secondly, that the proportion $(\rho)$ of phage, still remaining free when the dilution was made, which combined subsequently and multiplied in time to be released by the end of the incubation, was about 0.02 in tests nos. 2 and 3 , and between 0 and 0.02 in test no. 4 in which the dilution was longer delayed, so that the proportion of remaining free phage which could combine and multiply after the dilution was considerably smaller than $0 \cdot 02$.

The proportion $(x)$ of phage, combined before the dilution, that still multiplied, is then computed from the equation

$$
100 x P+100 \rho(1-P)+(1-\rho)(1-P)=r,
$$

where $r$ is the ratio of phage concentration at the end of the incubation to $\mathbf{1 3 0}$, which was the initial concentration.

Table 4 shows that most of the phage that combined with bacteria in the presence of $0.01 \%$ CTR did not multiply, although the concentration of CTR was later much below its limiting effective level. Only a small proportion of combined phage multiplied when the dilution was made within $10 \mathrm{~min}$. of mixing, and the proportion decreased further as the time was increased.

To see whether later stages of phage-host interaction can be affected, CTR 
was added to a mixture of phage and bacteria at various intervals after the two were mixed. Table 5 shows that in contrast to the decrease in concentration of active phage that occurred during $4 \mathrm{hr}$. incubation in mixtures in which CTR was added to a bacterial culture before or together with phage, the concentration of active phage increased when C'TR was added after adding phage, the increase being the greater the longer the interval of time between adding phage and CTR. (Even when the interval was decreased to the shortest possible, which was about $1 \mathrm{~min}$., the concentration of active phage increased slightly during $4 \mathrm{hr}$. incubation.) However, after the initial increases the concentrations of active phage dropped subsequently, which was apparent when a second assay was made after $24 \mathrm{hr}$. incubation.

\section{Table 4. Effect of interrupting the action of chymotrypsin by dilution}

Composition of mixtures: A: $3.2 \mathrm{ml}$. of $48 \mathrm{hr}$. bacterial culture $+0.4 \mathrm{ml}$. of $0.1 \%$ $\mathrm{CTR}+0 \cdot 4 \mathrm{ml}$. phage diluted $10^{-3}$. B: $3 \cdot 2 \mathrm{ml}$. of $48 \mathrm{hr}$. bacterial culture $+0 \cdot 4 \cdot \mathrm{ml}^{-} \mathrm{H}_{2} \mathrm{O}+$ $0 \cdot 4 \mathrm{ml}$. phage diluted $10^{-3}$. C: $3 \cdot 6 \mathrm{ml}$. of $48 \mathrm{hr}$. bacterial culture diluted $10^{-3}+0 \cdot 4 \mathrm{ml}$. phage diluted $10^{-6}$.

\begin{tabular}{|c|c|c|c|c|c|c|}
\hline \multirow{2}{*}{$\begin{array}{l}\text { Test } \\
\text { no. }\end{array}$} & & \multicolumn{2}{|c|}{$\begin{array}{l}\text { Concentration of } \\
\text { active phage after }\end{array}$} & \multirow{2}{*}{$\begin{array}{l}\text { Proportion } \\
\text { of phage } \\
\text { combined } \\
\text { before dilu- } \\
\text { tion } \\
(P)\end{array}$} & \multirow{2}{*}{$\begin{array}{l}\text { Assumed } \\
\text { proportion } \\
\text { of remaining } \\
\text { phage com- } \\
\text { bined after } \\
\text { dilution } \\
(\rho)\end{array}$} & \multirow{2}{*}{$\begin{array}{c}\text { Proportion } \\
\text { of phage, } \\
\text { combined } \\
\text { before dilu- } \\
\text { tion, that } \\
\text { multiplied } \\
(x)\end{array}$} \\
\hline & & $0 \mathrm{hr}$. & $4 \mathrm{hr}$. & & & \\
\hline 1 & A undiluted & $11 \times 10^{4}$ & $0.6 \times 10^{4}$ & - & - & - \\
\hline 2 & A dil. $10^{-3}$ after $10 \mathrm{~min}$. & & 500 & $(0 \cdot 2) \dagger$ & 0.02 & 0.07 \\
\hline 3 & A dil. $10^{-3}$ after $30 \mathrm{~min}$. & $(110)^{*}$ & 350 & $(0 \cdot 5$ & $0 \cdot 02$ & 0.025 \\
\hline 4 & A dil. $10^{-3}$ after $90 \mathrm{~min} . J$ & & 100 & $(0.9) \dagger$ & $0-0.02$ & $0.005-0.008$ \\
\hline $\mathbf{5}$ & B undiluted & $13 \times 10^{4}$ & $13 \times 10^{6}$ & - & - & - \\
\hline 6 & B dil. $10^{-3}$ after 1 & & 2900 & $0 \cdot 2$ & - & \\
\hline 7 & $\mathbf{B}$ dil. $10^{-3}$ after $\left.30 \mathrm{~min}.\right\}$ & $(\mathbf{1 3 0})^{*}$ & 6500 & 0.5 & - & $1 \cdot 0$ \\
\hline 8 & $\mathbf{B}$ dil. $10^{-3}$ after $90 \mathrm{~min} .5$ & & 11500 & 0.9 & - & \\
\hline 9 & C undiluted & $(130)^{*}$ & 400 & - & - & - \\
\hline
\end{tabular}

All the dilutions were made in the medium.

The fluids were kept at room temperature $\left(20^{\circ}\right)$ until the last dilutions of A and B were made in tests nos. 4 and 8 . Then all the fluids were incubated at $25^{\circ}$.

* The values of tests no. 1 and 5 , respectively.

$\dagger$ The values assumed equal to those of tests nos. 6,7 and 8 , respectively.

Evidently it is only during a minute or so, after combination between a phage particle and a bacterial cell has taken place, that they can be affected by CTR. Then a change occurs, possibly the entry of phage material into the cell or a process preliminary to it, after which CTR cannot affect the further processes leading to normal phage multiplication within the cell and the release of phage into the surrounding medium. As the time between adding phage and CTR increased, the proportion of phage that had combined with bacteria and passed the vulnerable stage also increased and, consequently, the proportion of phage that could multiply increased. However, the newly formed phage, released into the medium, combined with bacteria in the presence of CTR and became inactive. Hence the subsequent decrease 
following the initial increase in the concentration of active phage. Even the initial increase was underestimated by the assay, because by the time it was made a proportion of newly formed phage had combined with bacteria and become inactive.

\section{Table 5. Effect of varying time between adding phage and chymotrypsin to a culture of host bacteria}

The mixtures contained $4 \mathrm{ml}$. of a $24 \mathrm{hr}$. bacterial culture, $0.5 \mathrm{ml}$. of phage at a dilution of $10^{-5}$ and $0.5 \mathrm{ml}$. of $0.1 \% \mathrm{CTR}$ (the control had $0.5 \mathrm{ml} . \mathrm{H}_{2} \mathrm{O}$ instead of CTR), and were incubated at $25^{\circ}$.

CTR added:

$1 \mathrm{hr}$. before phage Together with phage 5 min. after phage 15 min. after phage 45 min. after phage Control (no CTR)
Concentration of active phage after

$\begin{array}{crc}0 \mathrm{hr} . & & \\ 750 & 4 \mathrm{hr} . & 24 \mathrm{hr} . \\ 700 & 90 & 20 \\ 1,100 & 110 & 20 \\ 2,000 & 20 \\ 7,000 & 230 \\ 20,000 & 430 \\ 97,000 & 95 \times 10^{7}\end{array}$

It is concluded that the CTR acts upon a freshly formed phage cell combination with the result that the phage particle combined with a bacterial cell remains inactive. There is at present no evidence to show whether the state of inactivity is the result of a structural alteration in the phage particle or of a reaction affecting only its junction with the cell, so that the particle cannot continue its normal interaction with the cell. Bacterial cells, on the other hand, which combined with phage in the presence of $0.01 \%$ CTR remained able to multiply (Table 6).

\section{Table 6. Ability of bacterial cells combined with phage in the presence of CTR to multiply and form colonies}

The mixtures were incubated for $1 \mathrm{hr}$. at $25^{\circ}$ and then diluted $10^{-5}$. One ml. samples of these dilutions were then mixed with $9 \mathrm{ml}$. of $0.7 \%$ agar medium, melted and cooled to $42^{\circ}$, and poured into Petri dishes. Bacterial colonies were counted after 5 days incubation at $25^{\circ}$.

Composition of mixtures :

$2 \mathrm{ml}$. of $24 \mathrm{hr}$. bacterial culture +

$\begin{array}{ccccc}\begin{array}{c}0.1 \% \\ \begin{array}{c}\text { CTR } \\ (\mathrm{ml})\end{array}\end{array} & \begin{array}{c}\mathrm{H}_{2} \mathrm{O} \\ (\mathrm{ml})\end{array} & \begin{array}{c}\text { Phage } \\ \text { (undil.) } \\ (\mathrm{ml} .)\end{array} & \begin{array}{c}\text { Medium } \\ (\mathrm{ml} .)\end{array} & \begin{array}{c}\text { Mean nos. } \\ \text { of colonies } \\ \text { per plate }\end{array} \\ 0.5 & - & 2 & - & 115 \\ - & 0.5 & 2 & - & 6 \\ 0.5 & - & - & 2 & 125 \\ - & 0.5 & - & 2 & 120\end{array}$

When the concentration of CTR in a liquid bacterial culture was $0.005 \%$, phage multiplication was not inhibited completely and permanently, but was delayed for 2-3 days (test no. 2, Table 2). Then the culture lysed and phage reached about the same concentration as in the absence of CTR.

Proteolytic activity of CTR in the lysed culture was assayed by a method based on rendering casein unprecipitable by trichloroacetic acid, and was 
found to be unaltered during incubation. The delayed phage multiplication did not, therefore, occur because of a decrease in the concentration of active CTR. The fact that the whole culture was lysed shows that it was not a bacterial mutant that interacted with the phage, for a mutant would have formed only a proportion of the culture. The phage that did multiply in the presence of CTR was not a mutant immune to the inhibitory effect of CTR as it was tested and found as susceptible as phage formed in the absence of CTR.

It is concluded that phage cell interaction can proceed in the presence of 0.005\% CTR, though its progress is then greatly slowed. The limiting concentration below which CTR has no effect, seems to be $c .0 .001 \%$ (test nos. 3 and 4 , Table 2).

It is not certain what happens when the concentration of CTR in a liquid medium is within the range where it does not stop phage multiplication completely but only delays it. The delay may occur because some stage of the interaction between all phage particles and bacteria is slowed or because some phage particles are inactivated, whereas a proportion interact at the normal rate.

The effect of CTR on phage-host interaction seems to be connected with its proteolytic activity, as neither chymotrypsinogen nor CTR whose proteolytic activity has been destroyed by heat, or by exposure to ultraviolet radiation, had any effect on phage-host interaction.

\section{Effects of killing bacteria by heat or ultraviolet radiation}

To check the conclusion that CTR inactivates the phage only when it is interacting with bacteria, experiments were made with bacteria killed by exposure to heat or to ultraviolet radiation.

Heating $48 \mathrm{hr}$. bacterial cultures, containing $c .5 \times 10^{6}$ bact./ml., for $5 \mathrm{~min}$. at $100^{\circ}$ destroyed the ability of bacteria to combine specifically with phage, although heat-killed bacteria, when used as more concentrated suspensions, can adsorb unspecifically small proportions of phage added to them (Kleczkowska, 1945 b). Phage added to this heated culture remained free, its concentration unaltered even after incubation for several hours at $\mathbf{2 5}^{\circ}$ and the addition of CTR had no effect.

Ultraviolet-killed bacteria may retain their ability to combine specifically with their phages (Garen \& Puck, 1951) and the ultraviolet-killed bacteria used in this work did retain it, although the rate of combination was somewhat decreased as a result of irradiation. A $48 \mathrm{hr}$. bacterial culture was irradiated so that the proportion of bacterial cells still able to form colonies was $1.5 \times 10^{-5}$ (see Table 7). When phage was added to this culture and assayed after $4 \mathrm{hr}$. incubation at $25^{\circ}$, the concentration of active phage was only about $14 \%$ of that added and this concentration remained unaltered when the ultravioletkilled bacteria were removed by centrifugation and the supernatant fluid was tested. Evidently phage that combined with ultraviolet-killed bacteria became inactive; it probably remained attached to them and so was not available to live bacteria. There is, therefore, a similarity between the result 
of combination of phage with ultraviolet-killed bacteria and with live bacteria in the presence of $0.01 \%$ CTR.

Table 7. Combination between phage and bacteria killed by ultraviolet radiation

\begin{tabular}{|c|c|c|c|c|c|c|c|}
\hline & & omposition & f mixtu & & Conce & tration of ac & ive phage \\
\hline & $\begin{array}{r}48 \mathrm{hr} . \\
\text { cul }\end{array}$ & $\begin{array}{l}\text { bacterial } \\
\text { ture }\end{array}$ & & & & After $4 \mathrm{~h}$ & $\begin{array}{l}\text { incubation } \\
\mathbf{2 5}^{\circ}\end{array}$ \\
\hline $\begin{array}{l}\text { Mixture } \\
\text { no. }\end{array}$ & $\begin{array}{l}\text { Non- } \\
\text { irradiated } \\
\text { (ml.) }\end{array}$ & $\begin{array}{l}\text { Irradiated } \\
\text { (ml.) }\end{array}$ & $\begin{array}{l}0.1 \% \\
\text { CTR } \\
\text { (ml.) }\end{array}$ & $\begin{array}{l}\mathrm{H}_{2} \mathrm{O} \\
\text { (ml.) }\end{array}$ & Initially & $\begin{array}{l}\text { Non- } \\
\text { centrifuged } \\
\text { culture }\end{array}$ & $\begin{array}{l}\text { Supernatant } \\
\text { fluid }\end{array}$ \\
\hline 1 & 4 & - & 0.5 & - ) & & 50 & - \\
\hline 2 & 4 & - & - & 0.5 & & 75,000 & - \\
\hline 3 & - & 4 & 0.5 & - & 730 & 95 & 100 \\
\hline 4 & - & 4 & - & 0.5 & & 100 & 95 \\
\hline
\end{tabular}

$0.5 \mathrm{ml}$. of phage stock culture diluted $10^{-5}$ added to each mixture, which was then incubated for $4 \mathrm{hr}$. at $25^{\circ}$. Samples of mixtures nos. 3 and 4 were then centrifuged for $15 \mathrm{~min}$. at 10,000 r.p.m. Phage was assayed in non-centrifuged cultures and in supernatant fluids of centrifuged samples.

The presence of $0.01 \%$ CTR in a mixture of phage and ultraviolet-killed bacteria had no effect on the phage. The rate of the latter's combination with the bacteria was unaffected by CTR, and combined phage became inactive irrespective of whether CTR was present or not.

\section{REFERENCES}

Garen, A. \& Puck, T. T. (1951). The first two steps of the invasion of host cells by bacterial viruses. II. J. exp. Med. 94, $17 \%$.

Kleczkowska, J. (1945 $a$ ). The production of plaques by Rhizobium bacteriophage in poured plates and its value as a counting method. J. Bact. 50, 71 .

KLeczkowska, J. (1945b). A quantitative study of the interaction of bacteriophage with Rhizobium using the technique of poured plates. J. Bact. 50, 81 .

KLeczkowski, A. \& KLeczkowski, J. (1951). The ability of single phage particles to form plaques and to multiply in liquid cultures. J. gen. Microbiol. 5, 346.

Kleczkowski, J. \& KLeczkowski, A. (1952). Effect of specific polysaccharides from the host bacteria and of ribonuclease on the multiplication of rhizobium phages. J. gen. Microbiol. 7, 340.

Northrop, J. H., Kunitz, M. \& Herriot, R. M. (1948). Crystalline Enzymes, 2nd ed. New York: Columbia University Press. 